\title{
Climate change in Africa and the Middle East in light of health, ubuntu and Islam
}

T Metz, BA, MA, PhD

Department of Philosophy and Institute for Pan-African Thought and Conversation, University of Johannesburg, South Africa

Corresponding author: TMetz (tmetz@uj.ac.za)

This article principally addresses the likely effects of global warming on health in developing countries in sub-Saharan Africa, northern Africa and the Middle East as well as how medical professionals, such as doctors, nurses, bioethicists and public health researchers, should respond to them in light of ubuntu and Islam, values characteristically held in those regions.

S Afr J Bioethics Law 2016;9(2):88-92. DOI:10.7196/SAJBL.2016.v9i2.489

My main task in this article is to provide an overview of current thought about how climate change, by which I primarily mean global warming, is expected to affect Africa and the Middle East, particularly when it comes to health in developing countries in those regions.

I do not address global warming alone but also briefly consider well-documented related environmental shifts such as oceanic acidification. I also address the implications of such environmental shifts for some values beyond that of health, in particular, moral goods held dear in certain regions that those working in medicine, public health, bioethics and related fields have reason to take into consideration. Specifically, I consider facets of global warming in light of not only what is widely known as ubuntu in sub-Saharan Africa, a view of human excellence obtained through communal relationships, but also some Islamic bioethical norms prominent in northern Africa and the Middle East.

After prognosticating about the likely effects of climate change on these regions and diagnosing moral concerns about them, I provide reason to think that those working in health have a duty to push for appropriate remedies in their respective locales and indicate some that they should take seriously.

\section{Climate change and related environmental shifts}

By 'climate change' I mean in the first instance the warming of the planet, most likely as a result of greenhouse gas emissions, as it has been happening so far and is expected to increase over the next several decades in the absence of radical measures. These processes have been firmly established by the scientific community ${ }^{[1,2]}$ (and recently analysed by a moral philosopher ${ }^{[3]}$ ) and I take them for granted in what follows. In this section, I note some related ecological concerns as they bear on Africa and the Middle East, which I downplay in this article but which merit exploration elsewhere as part of a complete picture about environmental shifts and their likely harms to human health.

Beyond industrial pollution and deforestation, consider that depletion of the ozone could be a concern for southern Africa in terms of not merely the expected effects of increased solar radiation such as cancers, but also unforeseen changes to the jet stream and hence to the climate. ${ }^{[4]}$ While the evidence suggests that the holes over the earth's poles are slowly reversing, the chemicals now typically being used to replace chlorofluorocarbons (CFCs), which had been largely responsible for ozone depletion, are themselves expected to contribute to global warming. ${ }^{[5]}$

In addition, it is worth addressing how the decrease of oxygen and the increase of $\mathrm{CO}_{2}$ in the world's oceans, which are also results of greenhouse gas emissions, ${ }^{[6,7]}$ are likely to affect Africa, the Middle East and other parts of the world. In 2013, a report emerged indicating that oceans are acidifying at a much greater rate than was thought, leading to noticeable changes to ecosystems, including losses of plankton, fish and other sea creatures. ${ }^{[8]}$

Finally, the bare fact of uncertainty with regard to climate change and other environmental shifts is a likely problem for developing countries. Suppose that it is correct, as I discuss below, that the effects of climate change are likely to be greatest in Africa and the Middle East, and suppose, too, that specific changes are substantially unpredictable, at least with regard to a particular country or region. In that case, because investors naturally want to avoid unpredictability, investment in these areas is likely to decrease, ${ }^{[9]}$ which would presumably leave people in a state of poverty and hence not well able to avoid disease and to afford healthcare.

\section{Climate change, health and ubuntu in sub- Saharan Africa}

It is commonly said that developing countries, particularly in Africa, are the least responsible for climate change, but will bear the greatest costs of it. ${ }^{[10,11]}$ Estimates of Africa's contribution to greenhouse gas emissions range from less than $4 \%{ }^{[11]}$ to no more than $7 \%,{ }^{[12]}$ and they would probably be on the low end once the oil producers in northern Africa were excluded (see the next section). Even if one is a sceptic about humankind being the source of global warming through $\mathrm{CO}_{2}$ production, it remains the case that, whatever the cause, higher temperatures will likely harm sub-Saharan Africa the most, not only because the effects in terms of drought, flooding and the like are expected to be the largest there, but also because that region most lacks the ability to cope with them. ${ }^{[12-15]}$ Still more, the negative effects of global warming specifically with respect to health are 
likely to be the worst in Africa, and particularly in the sub-Saharan region. ${ }^{[10-12]}$

The literature on climate change in Africa routinely notes that much of the continent (even beyond the Sahara desert) consists of drylands, that at least two-thirds of the economy is dependent on agriculture, that population growth is particularly high, that people tend to be socially and economically badly off, and that adaptive and governance mechanisms are typically poor. ${ }^{[11,13,15]}$ The combination of these factors makes the sub-Saharan region particularly vulnerable to changes in rainfall and water generally, whether they come in the form of, say, drought, on the one hand, or flooding, on the other. As is also often pointed out, harms expected from climate change are largely mediated through water: either there will be too little of it, or there will be too much of it, or it will be contaminated.

Four distinguishable water-related harms stand out in relation to health in sub-Saharan Africa.

First, in the event of drought and heat waves, which are expected to substantially increase in sub-Saharan Africa, ${ }^{[16]}$ more people would die directly from heat stress, and, in addition, people would have less access to fresh water, leading to increased vulnerability to disease as a result of reduced hydration and poorer hygiene. According to one widely cited document, the Stern Review, a temperature rise of $2^{\circ} \mathrm{C}$ would likely mean a $20-30 \%$ decrease in water availability in southern Africa, with a rise of $4^{\circ} \mathrm{C}$ projected to entail up to a $50 \%$ decrease..$^{10]}$

Second, consider the converse event of flooding, expected to result from storms and from oceans rising due to thermal expansion and ice sheet collapse. Inundation by water would increase risks of vector-borne diseases such as malaria and dengue fever, transmitted by mosquitoes (and also rats in the case of the latter), as well as risks of waterborne diseases such as cholera and typhoid. Again according to the Stern Review, ${ }^{[10]}$ a temperature rise of $2^{\circ} \mathrm{C}$ would likely entail that 40 - 60 million more people become exposed to malaria, which is well known for already killing at least half a million people (mostly children) in Africa every year. Another concern with regard to flooding is the state of people's mental health, with risks of depression, posttraumatic stress syndrome and related maladies identified. ${ }^{[17]}$

Third, whether it is drought or flooding, major changes to rainfall are strongly expected to impair food production. In addition, it appears that simply higher temperatures will 'reduce yields because crops speed through their development, producing less grain in the process.'[18] And less food, combined with substantial population growth, can be expected to result in an increase in the incidence of malnutrition and hence a greater susceptibility to disease, particularly diarrhoea, on the part of children. The Stern Review ${ }^{[10]}$ remarks: 'In many developing countries, even small amounts of warming will lead to declines in agricultural production because crops are already close to critical temperature thresholds. The human consequences will be most serious and widespread in Sub-Saharan Africa, where millions more will die...'

At a global level, some of the most well-respected work in the field, put out by the Intergovernmental Panel on Climate Change, indicates with 'medium confidence' that 'climate change would increase the number of hungry and malnourished people in the twenty-first century by 80 - 90 million',[19]

Fourth, any sort of extreme environmental shifts, which beyond drought and flash flooding could well include cyclone storms and rising oceans on the coasts, will probably lead to large-scale migration. Those in transit, at least those who are not pastoralists or other nomads accustomed to migrating, are particularly vulnerable to dehydration and malnutrition, and those who have settled in, say, slums are more likely to pick up diseases associated with poor sanitation. The Africa Partnership Forum, a collection of leaders from the African Union, the African Development Bank, the United Nations, the $\mathrm{G} 8$ and similar groups, says projections suggest 'that the number of people at risk from coastal flooding could increase from 1 million in 1990 to 70 million in 2080, forcing major population movements.'[11]

Another harm that the literature often mentions as expected from climate change south of the Sahara desert is that the above kinds of water-related effects would impair the ability to escape poverty and would probably worsen it. It is pointed out, for example, that about three-quarters of jobs in sub-Saharan Africa are based on agriculture, which, in turn, largely depends on rainfall. ${ }^{[20]}$ And poor harvests resulting in reduced income will bring in their wake inadequate medical facilities, a brain drain of medical personnel, the inability to afford preventive measures and treatments, and other sadly familiar outcomes.

Finally, one can expect drought, flooding, hunger, migration and poverty to increase social conflict, and perhaps even occasionally wars, beyond what the continent has already experienced since World War II. For example, consider the tens of millions of pastoralists in Eastern and Western Africa, who live in arid and semi-arid regions and are highly mobile, migrating to find water and to enable their livestock to graze. Given their tendency to move wherever they need to survive and flourish, pastoralists are disinclined to respect what they tend to see as artificial borders between countries or rules about ownership of land used for agriculture, ${ }^{[21]}$ with the Niger and Nile regions often mentioned as tinderboxes. ${ }^{[22,23]}$ Competition for aquifers and rivers could also prompt inter-state military strife. In summary, it is not merely illnesses that medical professionals south of the Sahara need to be concerned about, but also injuries.

In addition to these commonly discussed effects of global warming, I here mention some concerns that are not encountered in the literature, but that those in health-related fields have reason to take into account in relation to this region. In sub-Saharan Africa, the dominant approach to ethics is communal. It is commonly thought that one's basic aim in life should be to develop the higher, distinctively human parts of one's nature, which are conceived in relational or social terms. Specifically, many believe that one can realise oneself or display human excellence, i.e. ubuntu as it is known in the Nguni languages of southern African, only if (and even insofar as) one relates communally, by sharing a way of life with others and caring for their qualify of life. ${ }^{[24,25]}$ This basically means experiencing a sense of togetherness, engaging in joint projects, helping one another and doing so consequent to sympathetic and altruistic motivation.

Given this ethical orientation, disease and poverty can be seen to have certain ethical meanings that they usually do not have in, say, North America and Europe. For instance, according to an Afrocommunitarian ethic, it is of utmost importance to take care of one's family, and to give it priority relative to others. ${ }^{[26]}$ The fact of one's child being sick is bad, but one being unable to help one's child is worse (even if not an occasion for censure). Disease and poverty do not merely signify a poor quality of life for individuals; they also inhibit the kinds of sharing and caring relationships between 
individuals that indigenous sub-Saharans characteristically prize. Lacking resources essential to health, people cannot provide urgent goods to others with whom they identify, a key dimension of humanness or virtue. This is true for a head of household wanting to care medically for her children, as well as for hospitals and governments in relation to citizens.

Similarly, from a typically sub-Saharan moral standpoint, conflict or discord, in which people think of themselves as divided against one another, are in competition, and act in harmful ways without concern for the other's well-being, is in itself a serious moral wrong. Speaking of African ethical thought, Desmond Tutu, renowned chair of South Africa's Truth and Reconciliation Commission, remarks:

'Social harmony is for us the summum bonum - the greatest good. Anything that subverts or undermines this sought-after good is to be avoided like the plague. Anger, resentment, lust for revenge, even success through aggressive competitiveness, are corrosive of this good.[27] Hence, people contesting one another for scarce medical resources or fighting over water, for instance, would be unwelcome from this perspective not merely because of the harm inflicted, but particularly because of the denigration of the relationship between people into one of enmity.

It might not be possible for those working on health matters south of the Sahara desert to prevent climate change or its immediate effects on populations there (though I discuss a few strategies in the conclusion); even so, they could try to encourage people to react to crises by pulling together instead of being divisive and exhibiting ill-will. Sometimes when natural or other disasters strike a society, people can be prompted to identify with one another and to exhibit solidarity with each other. So, developing rationing systems in which everyone is clearly given a fair chance might be one way to get people not to become overly focused on themselves and those close to them to the point of being willing to steal, bribe, cheat or coerce. Another potential strategy might be to draw on aspects of ubuntu that emphasise the idea that everyone, regardless of nationality, race and the like, has a dignity and is part of a human family, roughly is a person with whom to commune (at least if innocent). Such an attitude largely underlay the common pre-colonial practice of welcoming visitors to a village with food and shelter. Reinvigorating that strand of ethical thought in the subSaharan region might be a promising strategy by which to respond to scarcity and hardship.

No one expects uniformly negative results to come from global warming in sub-Saharan Africa. For instance, there is some evidence that farmers with 'heat-tolerant' livestock such as goats and sheep would benefit from warming, ${ }^{[13]}$ and it could be that an increase in $\mathrm{CO}_{2}$ would improve yields of certain crops by enhancing photosynthesis. ${ }^{[18]}$ In addition, perhaps human pluck and ingenuity will turn out to find solutions: a promising new malaria vaccine might be forthcoming, ${ }^{[28]}$ and novel techniques for detecting underground water have been deployed in Kenya. ${ }^{[29]}$

However, no respectable source, of which I am aware, welcomes global warming on the whole, especially in sub-Saharan Africa. And while any beneficial effects of climate change and innovative preventions of harm from it are to be appreciated, it is hardly the case that people, and especially those in positions of influence, may relax in the expectation that things will turn out just fine. For all the scientific community can tell, some severe harms are likely to result from global warming south of the Sahara, and professionals with education and power have some obligation to attend to them.

This view of obligation is particularly plausible in light of the communal ethic that is salient in the region. Traditional African moral norms are well known for imposing weighty duties to help others on those with know-how, responsibility, wealth and the like. Indeed, a characteristically African approach to ethics is plausibly understood not to include a category of supererogation, viz. not to morally permit one to do anything less than all one can to help others. ${ }^{[30]}$ Hence, in order to adequately develop their humanness, their ubuntu, medical professionals such as physicians and medical ethicists should identify with patients and the broader society and work towards preventing climate change, the harmful outcomes for health that are likely to result from it, and the failures to commune (if not instances of outright discord) that might occur consequent to such harms. In the conclusion I provide some guidance, after discussing the expected condition of many Islamic countries in light of global warming.

\section{Climate change, health and Islam in northern Africa and the Middle East}

On the face of it, there are substantial differences between the countries south of the Sahara, on the one hand, and those north of and in the Middle East, on the other. In terms of culture, those in the sub-Saharan region are mainly indigenous black peoples who favour some form of animist Christianity, whereas those in northern Africa and the Middle East tend to be of Arab descent (setting aside glaring exceptions such as Israel and Iran) and to practise Islam. The subSaharan countries do not feature nearly as much outright desert as do those in northern Africa and the Middle East. And the former emit among the lowest per capita greenhouse gas emissions in the world, whereas the latter emit among the highest, with Qatar, Saudi Arabia, Kuwait, the United Arab Emirates and Oman topping the list. ${ }^{[31]}$

However, these sorts of distinctions make little difference when it comes to the likely effects of global warming on human health. With respect to this matter, the similarities between the regions are instead what are salient. Specifically, both parts of the world in the following are all very high: population growth, poverty, dry lands and residence on coasts. What has made it sensible to have a combined discussion of Africa as a whole and the Middle East is that both exhibit large and growing numbers of people living substantially on ocean fronts, experiencing economically impoverished conditions, and lacking substantial access to clean fresh water. These commonalities make northern Africa and the Middle East, like sub-Saharan Africa, particularly vulnerable to global warming. ${ }^{[10,32]}$

A survey of the literature on climate change in northern Africa and the Middle East ${ }^{[13,32-35]}$ turns up the same negative outcomes with regard to health discussed in the previous section. That is, scientists and analysts expect this part of the world to be at great risk of: drought and heat waves, flooding (especially on the coasts as a result of rising oceans), reduced agricultural output, migration and, as a result of these, poverty and conflict. The same concerns about malnutrition, dehydration, diseases and injuries are pertinent.

Even if the consequences are expected to be similar in both parts of the world, the ways they are morally interpreted will tend to differ. In particular, the Islamic tradition of northern Africa and the Middle East exhibits certain approaches to bioethics, which I will now discuss in relation to global warming. 
If a crude summary of one major swathe of ethical thought in regions south of the Sahara is summed up by 'honour communal relationships', one similar in form with respect to areas north of the Sahara and in the Middle East would be 'obey Allah'. Central to Islam is the view that one's basic duty in life should be to conform to God's commands, viz. to avoid doing what He has forbidden and discouraged, and to do what He has required and encouraged, particularly as expressed in the Qur'an, but also as implied by Mohammed's doings and sayings (Hadith). God is understood to have conferred a dignity on human beings, and to have commanded people to treat one another justly and beneficently.

With regard to Islamic bioethics, a large majority of articles, books and other discussions focus on either relationships between doctors and patients, on the one hand, or sanctity of life matters such as abortion, euthanasia and biotechnology, on the other. However, some guidance from the Muslim tradition about how medical professionals should respond to more large-scale issues is found in two key documents.

First, there is the Oath of a Muslim Physician, which was developed to be an Islamic version of the Hippocratic Oath, and so, for instance, replaces talk of 'gods' in the latter with mention of 'God'. One English version of the Oath of a Muslim Physician is found in the second major source, namely, the Islamic Code of Medical Ethics, first drafted in 1981 by the Islamic Organisation for Medical Sciences (IOMS) in Kuwait. ${ }^{[36]}$ IOMS has spearheaded efforts in the Muslim world to reflect collectively and systematically on bioethical issues, and it later, in consultation with the World Health Organization (WHO) and the Council for International Organizations of Medical Sciences (CIOMS), substantially revised the code, which is now known as the Islamic Code of Medical and Health Ethics. ${ }^{[37]}$ Both the Oath and the Code address duties with respect to health at the social level.

By the Oath, a physician swears to 'protect human life in all stages and under all circumstances' and 'to be, all the way, an instrument of God's mercy, extending my medical care to the near and far! ${ }^{[36]} \mathrm{A}$ straightforward reading of these commitments suggests that doctors, and presumably related practitioners in medicine and health, have some obligation to be concerned for the social determinants of health and their opposites of illness and injury.

Still more, the Code includes a section titled 'Doctor and Society', where one finds the explicit claims in the initial draft that the 'Doctor's mission exceeds the treatment of disease to taking all measures to prevent its occurrence' and that the 'combat and prevention of environmental pollution falls under this category! ${ }^{[36]}$ In addition, in the more recent draft of the Code, one finds articles such as these: 'A physician should help society in dealing with elements of health enhancement, disease prevention, and protection of the natural and social environment', and 'A physician, particularly when holding an official position, should take an active part in setting regulations, drawing health policies, and solving health problems, thus serving the interests of the community.[37]

Surely, what goes for a physician applies to other professionals in the fields of medicine and health. From an Islamic perspective, then, in order to abide by God's will, those in such professions must do what they reasonably can to prevent global warming and its negative effects on the dignity of human life. What such behaviour might plausibly involve I briefly discuss in the concluding section of this article.

\section{Some concluding recommendations}

It is interesting to see how the non-Western ethical perspectives addressed in this article naturally entail social obligations of medical professionals with regard to global warming. These approaches differ in this respect from, say, the Four Principles and North American codes of medical ethics, which focus nearly exclusively on relationships between doctors/nurses and stakeholders such as patients, other doctors/nurses, insurance companies and so forth. What, then, should physicians, hospital administrators, bioethicists, and public health researchers, particularly those living in Africa and the Middle East, do? Although the developed world clearly has the principal obligation to reduce global warming and to compensate such regions for harms it has caused them, in the absence of such measures in the near term how can locals help to mitigate the expected harms?

At the very least, medical professionals in developing countries could collect information about the apparent effects of global warming on health and related values. Knowing what is happening would help governments, non governmental organisations and other agents such as the United Nations to respond where medical professionals themselves cannot.

In addition, medical professionals could help to develop guidelines for prioritising and rationing the distribution of scarce resources. Knowing, for instance, that it would be cheaper to fight diarrhoea than malaria, supposing one could not afford to address both, ${ }^{[38]}$ would help to save lives.

Somewhat more pro-actively, medical professionals could work to develop relevant vaccines, to contribute to mobile clinics, and to transfer medical skills to lay people in local settings. They could also take an interest in working with other agents to try to prevent waterrelated harms by, say, promoting early-warning systems, enabling communities to collect rainwater as opposed to relying so heavily on ground water, providing the tools and skills that would enable people to irrigate their crops instead of waiting for rain, and supporting reforestation projects (such approaches are commonly suggested in the literatur $\left.{ }^{[39,40]}\right)$. Although these kinds of activities are beyond the normal remit of a medical professional, as has been discussed in this article neither ubuntu nor Islam restricts duties to narrow roles, and instead both by and large instruct those who can to do.

Acknowledgements. A close relative of this article originally appeared as a chapter (with more detailed page references) in Macpherson C, ed. Bioethical Insights into Values and Policy: Climate Change and Health. Dordrecht: Springer, 2016:115-125. [DOI:10.1007/978-3-319-26167-6_9]. It is reprinted here with the generous permission of Springer. For written comments on drafts leading up to this publication, I am grateful to Hennie Lötter, Cheryl Macpherson and Darrel Moellendorf. Camilla Boisen also gave me an idea in passing conversation, for which I am thankful.

\section{References}

1. Intergovernmental Panel on Climate Change (IPCC). Climate Change 2013: The Physical Science Basis. Geneva: Intergovernmental Panel on Climate Change 2013. http://www.ipcc.ch/report/ar5/wg1/ (accessed 2 July 2016)

2. World Meteorological Organization (WMO). A summary of current climate change findings and figures. Geneva: WMO, 2013. http://www.unep.org/ climatechange/Publications/Publication/tabid/429/language/en-US/Default. aspx?|D=6306 (accessed 2 July 2016). 
3. Moellendorf D. The Moral Challenge of Dangerous Climate Change. Cambridge: Cambridge University Press, 2014

4. Kang SM, Polvani LM, Fyfe JC, Sigmond M. Impact of polar ozone depletion on subtropical precipitation. Science 2011;332(6032):951-954. DOI:10.1126/ science.1202131

5. Fergusson A. Ozone depletion and climate change: Understanding the linkages. Ontario: Minister of Public Works and Government Services, 2001. http://es-ee. tor.ec.gc.ca/e/ozone/OzoneDepletionClimateChange.pdf (accessed 2 July 2016).

6. Doney SC. The dangers of ocean acidification. Sci Am 2006;294(3):58-65. DOI:10.1038/scientificamerican0306-58

7. Rogers $A D$, Laffoley $D$. International earth system expert workshop on ocean stresses and impacts. Oxford: International Programme on the State of the Ocean (IPSO), 2011. http://www.cacoastkeeper.org/document/international-workshopon-ocean-stresses-and-impacts.pdf (accessed 2 July 2016).

8. International Programme on the State of the Ocean (IPSO). State of the Ocean Report 2013. Oxford: International Programme on the State of the Ocean, 2013. http://www. stateoftheocean.org/science/state-of-the-ocean-report/ (accessed 2 July 2016).

9. African Development Bank. Bank Group Climate Risk Management and Adaptation Strategy. Côte d'Ivoire: African Development Bank, 2009 http://www. afdb.org/fileadmin/uploads/afdb/Documents/Policy-Documents/Climate\%20 Risk\%20Management\%20and\%20Adaptation\%20Strategy\%20_CRMA_\%20(2). pdf (accessed 2 July 2016).

10. Stern N. Stern Review: The Economics of Climate Change. United Kingdom: Chancellor of the Exchequer, 2005. http://mudancasclimaticas.cptec.inpe.br/ rmclima/pdfs/ destaques/sternreview_report_complete.pdf (accessed 2 July 2016).

11. Dahou K, Kibuka-Musoke D, Ngo B, Pavarini F. Climate challenges to Africa, a call for action. OECD Journal 2012;2(4):7-112. DOI:10.1787/gen_papers-2010$5 \mathrm{k} 9$ btsvgg $5 \mathrm{~d}$

12. African Development Bank. The Cost of Adaptation to Climate Change in Africa. Côte d'Ivoire: African Development Bank, 2011. http://www.afdb.org/ fileadmin/uploads/afdb/Documents/Project-and-Operations/Cost $\% 20$ of\%20 Adaptation\%20in\%20Africa.pdf (accessed 2 July 2016).

13. Boko M, Niang A, Nyong C, et al. Africa. In: Parry ML, Canziani JP, Palutikof $P$, et al., eds. Climate Change 2007: Impacts, Adaption and Vulnerability. Contribution of Working Group II to the Fourth Assessment Report of the Intergovernmental Panel on Climate Change. Cambridge: Cambridge University Press, 2007:433467. http://www.ipcc.ch/pdf/assessment-report/ar4/wg2/ar4-wg2-chapter9.pdf (accessed 2 July 2016).

14. Intergovernmental Panel on Climage Change. African Ministerial Conference on the Environment (AMCEN). Fact sheet: climate change in Africa - what is at stake? Geneva: Intergovernmental Panel on Climate Change, 2007. http://www. unep.org/roa/amcen/docs/AMCEN_Events/climate-change/2ndExtra_15Dec/ FACT SHEET CC Africa.pdf (accessed 2 July 2016).

15. World Bank. Making development climate resilient: A World Bank strategy for sub-Saharan Africa. Washington: World Bank, 2009. http://siteresources. worldbank.org/INTAFRICA/Resources/ClimateChange-StrategyReport2010-Full_ vNolmages.pdf (accessed 2 July 2016).

16. Lyon B. Southern Africa summer drought and heat waves: Observations and coupled model behavior. J Climate 2009;22(11):6033-6046. DOI:10.1175/2009JCLI3101.1

17. Ahern M, Kovats RS, Wilkinson P, Few R, Matthies F. Global health impacts of floods: Epidemiologic evidence. Epidemiol Rev 2005;27:36-46. DOI:10.1093/ epirev/mxi004

18. Cline W. Global Warming and Agriculture. Washington: International Monetary Fund, Finance and Development 2008:3:23-27. http://www.imf.org/external/ pubs/ft/fandd/2008/03/pdf/cline.pdf (accessed 2 July 2016).

19. Campbell-Lendrum DH, Corvalan CF, Pruss-Ustin A. How much disease could climate change cause? In: McMichael AJ, Campbell-Lendrum DH, Corvalan CF, et al., eds. Climate Change and Human Health: Risks and Responses. Geneva: World Health Organization, 2003:133-158. http://www.who.int/entity/globalchange/ publications/climchange.pdf (accessed 2 July 2016).

20. Lisk F. Overview: The current climate change situation in Africa. In: Besada $\mathrm{H}_{\text {, }}$ Sewankambo N, eds. Climate Change in Africa: Adaptation, Mitigation and Governance Challenges. Ontario: The Centre for International Governance Innovation, 2009:8-15. http://www.unicef.org/esaro/Climate_Change_in_Africa. pdf (accessed 2 July 2016).
21. Oxfam International. Survival of the fittest: Pastoralism and climate change in East Africa. Oxford: Oxfam International, 2008. http://www.oxfam.org/sites/www. oxfam.org/files/bp116-pastoralism-climate-change-eafrica-0808.pdf (accessed 2 July 2016).

22. Hsiang SM, Burke M, Miguel E. Quantifying the influence of climate on human conflict. Science 2013;341(6151):1235367. DOI:10.1126/science.1235367

23. Kloos J, Gebert N, Rosenfeld T, Renaud F. Climate Change, Water Conflicts and Human Security: Regional Assessment and Policy Guidelines for the Mediterranean, Middle East and Sahel. Bonn: United Nations University Institute for Environment and Human Security, 2013. http://collections.unu.edu/eserv/ UNU:1848/pdf11351.pdf (accessed 2 July 2016).

24. Metz T. Ubuntu: The good life. In: Michalos A, ed. Encyclopedia of Quality of Life and Well-Being Research. Dordrecht:Springer, 2014:6761-6765. DOI:10.1007/97894-007-0753-5

25. Metz T. An overview of African ethics. In: Ukpokolo I, ed. Themes, Issues and Problems in African Philosophy. New York: Palgrave Macmillan, 2016:61-75. DOI:10.1007/978-3-319-40796-8

26. Appiah A. Ethical systems, African. In: Craig E, ed. Routledge Encyclopedia of Philosophy. London: Routledge, 1998.

27. Tutu D. No Future without Forgiveness. New York: Random House, 1999.

28. Seder RA, Chang LJ, Enama ME, et al. Protection against malaria by intravenous immunization with a nonreplicating sporozoite vaccine. Science 2013;341(6152):1359-1365. DOI:10.1126/science.1241800

29. Gramling C. Water resources. Kenyan find heralds new era in water prospecting Science 2013;341(6152):1327. DOI:10.1126/science.341.6152.1327

30. Gyekye K. Communitarianism and supererogationism. In: Gyekye K. Tradition and Modernity. New York: Oxford University Press, 1997:69-75.

31. World Bank. $\mathrm{CO}_{2}$ Emissions (metric tons per capita). Washington:World Bank, 2011. http://data.worldbank.org/indicator/EN.ATM.CO2E.PC/countries?display=map (accessed 2 July 2016).

32. Sowers J, Weinthal E. Climate Change Adaption in the Middle East and North Africa: Challenges and Opportunities. Dubai: The Dubai Initiative, Working Paper 2, 2010. http://pubpages.unh.edu/ jlu36/climate_change_adaptation.pdf (accessed 2 July 2016).

33. Pilifosova 0. Middle East and Arid Asia. In: Watson RT, Zinyowera MC, Moss RH, Dokken DJ, eds. The Regional Impacts of Climate Change: An Assessment of Vulnerability. Cambridge: Cambridge University Press, 1997:ch 7. http://www. grida.no/publications/other/ipcc\%5Fsr/?src=/climate/ipcc/regional/index.htm (accessed 2 July 2016).

34. Medany M. Impact of climate change on Arab countries. In: Tolba M, Saab N, eds. Arab Environment: Future Challenges. Beirut: Arab Forum for Environment and Development, 2008:127-136. http://www.afedonline.org/afedreport/english/ book9.pdf (accessed 2 July 2016).

35. Brown O, Crawford A. Rising Remperatures, Rising Tensions: Climate Change and the Risk of Violent Conflict in the Middle East. Winnipeg: International Institute for Sustainable Development, 2009. https://www.iisd.org/pdf/2009/rising temps_middle_east.pdf (accessed 2 July 2016).

36. Islamic Organization for Medical Sciences (IOMS). Islamic Code of Medica Ethics. Kuwait: Islamic Organization for Medical Sciences, 1981. http://hhlf.org/ ISLAMICCODEOFMEDICALETHICES.pdf (accessed 2 July 2016).

37. Islamic Organization for Medical Sciences (IOMS). Islamic Code of Medical and Health Ethics. Kuwait: Islamic Organization for Medical Sciences, 2004. http:// islamset.net/ioms/code2004/index.html (accessed 2 July 2016).

38. Markandya A, Chiabai A. Valuing climate change impacts on human health. Int J Environ Res Public Health 2009;6:759-786. DOI:10.3390/ijerph6020759

39. Besada H, Sewankambo N, eds. Climate Change in Africa: Adaptation, Mitigation and Governance Challenges. Ontario: The Centre for International Governance Innovation, 2009. http://www.unicef.org/esaro/Climate_Change_in_Africa.pdf (accessed 2 July 2016).

40. Millennium Development Goal Achievement Fund. Enabling pastoral communities to adapt to climate change and restoring rangeland environments programme. New York: Millennium Development Goal Achievement Fund, 2011. http://www.mdgfund.org/node/4040 (accessed 2 July 2016) 